\title{
GRANT CONTRACT AS A CIVIL LAW FORM OF ACTION OF THE PROVINCIAL MONUMENT CONSERVATOR IN THE POLISH LEGAL SYSTEM*
}

\author{
JACEK TRZEWIK**
}

\begin{abstract}
The legal issue of protection of monuments and guardianship of monuments seems to be a substantial challenge for the national legislator. Its significant role comes from the fact that it fulfils the postulate of protection both of the public interest related to the preservation of the cultural heritage for future generations, as well as the protection of the private interest related to the necessity of ensuring the possibility of use of the monument by its owner or another person holding a legal title to the monument. Because of its practical significance, a special role in the legal system of protection and guardianship of the monuments is played by the system of financial support granted by the state authorities to individual monument holders. The purpose of this article is to present a legal characteristic of the grant contract concluded by and between provincial conservators of monuments and monument holders for conservation, restoration and construction works at monuments listed in the national registry of monuments. The grant contract constitutes a specific legal form of consensual operation of a public authority.
\end{abstract}

Keywords: provincial conservator of monuments; contract; grant

Klíčová slova: provinční správce památek; smlouva; grant

DOI: $10.14712 / 23366478.2019 .16$

\section{INTRODUCTION}

Cultural heritage is a reflection of the world's history and our past. It is a testimony of our past lives. Heritage of humanity gives us the answer to the question of who we are and where we are heading in the era of dynamic socio-economic, technological and cultural progress. In this context, monuments are the most important element creating the material cultural heritage. ${ }^{1}$ Their protection is currently of global

* The article was written as part of the project entitled "Legal forms of action of the Provincial Heritage Conservation Officer" (Reg. no. 2015/19/B/HS5/02525) within the framework of which research was funded by the National Science Centre, Poland.

** Doctor of Laws, assistant professor, 1st Department of Civil Law, Faculty of Law, Canon Law and Administration, John Paul II Catholic University of Lublin, Al. Racławickie 14, 20-950 Lublin, e-mail: trzewik @kul.pl.

1 CHARYMSKA, E. Zabytki i dzieła sztuki jako przedmioty ochrony. De Securitate et Defensione. O Bezpieczeństwie i Obronności, 2015, no. 1, p. 32. 
significance, regardless of the location of the monument in any country and part of the world. National actions taken to protect monuments, without the synergy of international cooperation, are inadequate. At the same time, individual countries adopt specific regulations for the protection of monuments, vested in their legal culture. ${ }^{2}$

The system and organization of public bodies responsible in the Polish legal system for the protection and guardianship of monuments is determined by the regulation of the Basic Law. The obligation to protect monuments and cultural heritage is directly stipulated in the provisions of the Constitution of the Republic of Poland. ${ }^{3}$ Already in the preamble, it announces the commitment to pass on to future generations all that is valuable from over a thousand years of achievements of the nation. In addition, its provisions make relatively numerous references not only to the protection of the common good of all citizens (Articles 1 and 82 of the Constitution of the Republic of Poland), but also the protection of the national heritage, cultural assets or national cultural heritage (Article 5, Article 6 clause 1 and 2, and Article 73 of the Constitution of the Republic of Poland).

The Act on the Protection of Monuments and the Guardianship of Monuments plays a leading role in the implementation of the constitutional assumptions of monument protection at a statutory level. ${ }^{4}$ Above all, it defines the object, ${ }^{5}$ scope and forms of protection of monuments and their guardianship, as well as the guidelines for the creation of a national programme for the protection and guardianship of monuments. ${ }^{6}$ Importantly,

2 For more, see ZEIDLER, K. Źródła międzynarodowego prawa ochrony dziedzictwa kultury. Studia Europejskie, 2003, vol. XI.

3 Constitution of the Republic of Poland of April 2, 1997 (Journal of Laws No. 78, item 483, as amended [hereinafter: Constitution of the Republic of Poland]).

4 The Act of 23 July 2003 on the Protection of Monuments and the Guardianship of Monuments, uniform text Journal of Laws of 2017, item 2187, as amended [hereinafter: APM].

5 Pursuant to Art. 3 item 1 of the APM, a monument is understood as a real estate or movable item, their parts or assemblies, created by man or related to his activity and being a testimony to a bygone era or event, the preservation of which is in the public interest due to their historical, artistic or scientific value. Importantly, this definition does not take into account the formal criterion associated with the obligation to enter the monument in the register of monuments. Therefore, if a real estate or movable property meets the characteristics of a monument, it should be considered a monument, regardless of its formal form of protection. As a consequence, the objects and structures which are subject to protection and guardianship, regardless of their state of preservation, are: immovable monuments (being, in particular, cultural landscapes, urban and rural layouts and building complexes, architectural and construction works, defence works, technical facilities, in particular mines, steel mills, power plants and other industrial plants, cemeteries, parks, gardens and other forms of designed greenery, places commemorating historical events or the activities of outstanding personalities or institutions), movable monuments (being, in particular, works of visual arts, artistic handicraft and applied art, collections of items collected and ordered according to the concept of persons who assembled them, numismatics and historical mementos, especially military items, banners, seals, badges, medals and orders, products of technology, especially devices, means of transport and machines as well as tools that testify to material culture, characteristic for old and new forms of industry, documenting the level of science and civilization development, library materials, musical instruments, products of folk and handicraft art and other ethnographic objects, objects commemorating historical events or the activities of outstanding personalities or institutions), and, finally, archaeological monuments (which are, in particular, field remains of prehistoric and historical settlement, cemeteries, mounds, relics of economic, religious and artistic activity). The protection may also apply to geographical, historical or traditional names of buildings, squares, streets or settlement units (Article 6 clause 1 and 2 of the APM).

6 The Act lists the following legal forms of protection of monuments: entry into the register of monuments, entry into the Heritage Treasures List, recognition as a monument of history, creation of a cultural park, as well as establishing protection in the local spatial development plan or in the decision on the location of public purpose investment, decision on conditions of development, road investment permit, decision on the 
it also regulates the principles of financing of conservation, restoration and construction works concerning monuments, and, especially, the organization of monument conservation bodies.

Under the Act on the Protection of Monuments and Guardianship of Monuments, the latter term was given a meaning different from protection. This separation is mainly of a subjective nature, indicating that the protection of monuments is subject to implementation by public administration bodies, thus encompassing governing activities, whereas the guardianship of monuments is exercised by other entities, in particular owners or holders of monuments ${ }^{7}$. In addition, the legislator intended this concept to be interpreted strictly as one serving the purpose of determining the scope of rights and obligations of owners or holders of monuments, ${ }^{8}$ primarily related to care of monuments aimed at preserving them for the posterity.

location of the railway line or the building permit for public use airports (Article 7 of the APM). Among the protective activities, the register of monuments, including immovable, movable and archaeological monuments, is of fundamental importance. Entry into the register is done on request of the owner of an immovable or movable monument (and also of the perpetual lessee of the land on which the immovable monument is located) or ex officio, based on a decision issued by the provincial conservator of monuments (Article 9 clause 1 and 10 items 1 to 2 of the APM). It gives rise to important legal effects, not only by taking under legal protection a historic object (imposing a number of protective obligations on the owner and user of the monument), but also by giving the owners of the monument covered by this form of protection the right to purchase the monument at a reduced price (the price of a real estate or its part owned by the State Treasury or a unit of the territorial self-government and listed in the register of monuments is reduced by half, whereas the amount of the discount is subject to modifications - Article 68 clause 3 of the Act of 21 August 1997 on Real Estate Management, consolidated text Journal of Laws of 2018, item 121, [hereinafter: AREM].

7 ZEIDLER, K. Prawo ochrony dziedzictwa kultury. Warszawa, 2007, p. 137.

8 In the Polish legal system, the owner of a monument responsible for the guardianship of monuments is either its proprietor (which may be the State Treasury or an entity that is not part of the structure of the state) or its holder (who owns the monument on the basis of a specific legal title, including the basis of ownership). There is no direct legal exemption in this respect with regard to entities potentially entitled on account of the ownership of the monument. However, due to the need to pursue the public interest, the emanation of which is the obligation to protect monuments, the rights of the owner of a monument are subject to numerous limitations. Limitations in the right of ownership of a monument apply to all areas of an owner's rights. One can mention here the limitation in the right of possession of a monument listed in the register of monuments, to the extent that the monument protection authority may, by way of an administrative decision, order the monument to be made available for the period necessary to carry out research (Article 30 of the APM), or control the observance and application of provisions on monument protection (Article 38 of the APM). The competent authority may also, in certain circumstances, effect its temporary seizure (Article 50 clauses 1-3 of the APM) or even permanent deprivation of possession (Article 50 clause 4 of the APM). Relevant restrictions also apply to the right to use a listed property, as in the case of using a monument listed in the register, when a number of activities related to its use, including construction works on the monument, require the consent of the provincial conservator of monuments (Article 36 clause 1 of the APM). Moreover, the rights of the owner of a monument listed in the register in the scope of the right to wear or damage the monument are completely excluded - violation of this prohibition results in administrative liability (Article 107a of the APM) and criminal liability (Article 108 of the APM). An important limitation of the rights of the monument's owner in the scope of its disposal is the statutory right of pre-emption of monuments, which is in the case of historical real estates vested in communes and municipalities, pursuant to Art. 109 of the AREM, and in the remaining cases it is vested in museums by virtue of Art. 20 of the Act of 21 November 1996 on museums, consolidated text given in The Journal of Laws of 2018, item 720. However, thus designed system which interferes with the scope of rights of monument owners for the sake of protection of monuments has been assessed by the European Court of Human Rights as too restrictive and as one that violates the principle of proportionality in limiting the right of ownership of an individual due to the lack of proper compensation for the owner of the monument. Cf. judgements 
It seems, however, that in a broad sense the concept of guardianship of monuments should also be applied to public entities, even though they are not holders of monuments. However, they have statutory competences to carry out specific activities in the care of monuments as these have also been granted to government administration bodies, local government administration authorities, cultural institutions specializing in the guardianship of monuments as well as public keepers of monuments. As a result, public administration bodies which have obtained a wide range of competences in the sphere of protection and guardianship of historic buildings have become, next to the actual monument holders and administrators, their statutory, official guardians. ${ }^{9}$

The list of heritage protection authorities specified by the act includes the minister competent for culture and protection of national heritage as well as the voivode (governor) as the central government administration authority in the voivodeship (province). On their behalf, statutory tasks and competences in the field of protection and guardianship of monuments are performed respectively by the General Conservator of Monuments and the provincial conservator of monuments (Article 89 of the APM).

In this context, however, it is impossible to neglect the role of the owner of a historic building. The Act on the Protection of Monuments and Guardianship of Monuments imposes not only a moral but primarily a legal obligation on the owner or holder of a monument to take proper care of it. According to Article 5 of the APM, this involves, in particular, providing conditions for conservation, restoration and construction works at the monument. The listed duties are of individual character, which means that the owner or holder of the monument is directly responsible for their implementation. The role of monument protection authorities is here to exercise governing control over one's compliance with obligations imposed by the law. The state supports the fullest possible implementation of those obligations and the law provides for a possibility of adequate financial assistance given to holders of historic monuments.

In this context, it seems legitimate to ask whether the legislative solutions adopted in the Polish legal system allow to effectively achieve the objectives of monument protection and guardianship through civil law contracts concluded by and between provincial monument conservators and natural persons or organizational units operating under or outside the public sector framework. Conclusion of a grant contract in favour of an owner or holder of a monument is in fact the only statutory example of the implementation of a public task by the provincial monument conservator by way of a civil law contract; however, it has not yet been directly analysed in the literature. Therefore, this concept will be the subject of further deliberations.

of the European Court of Human Rights of 22 June 2004, application no. 31443/96, and of 19 June 2006, application no. 350014/97.

9 BRUDNICKI, J. Prawna opieka nad zabytkami - wybrane aspekty. Ochrona Zabytków, 2014, no. 2, p. 49. 


\section{OUTLINE OF THE LEGAL FORMS OF ACTION OF THE PROVINCIAL MONUMENT CONSERVATOR}

In view of the considerable bulk of public tasks to be implemented, the system of public administration bodies in Poland has at its disposal an equally impressive group of legal forms of action. Their identification is possible both in the sphere of internal activities, undertaken in relation to entities subordinate in terms of organization or obligations, as well as in external relations of the administration involving entities which are not subordinate in terms of organisation or tasks to the other party, or are outside the structure of public administration.

In accordance with the view prevailing in the literature, the legal forms of action of administration authorities in the context of external relations include the legislation of normative acts, issuing administrative acts, entering into administrative agreements, concluding contracts, organising social activities and performing material and technical activities. On the other hand, in internal relations there are no agreements, settlements or contracts, and the legislation of universally applicable laws and administrative acts takes the form of official orders. ${ }^{10}$ Thus, because of the need for the most effective implementation of public tasks, among the legal forms of action, the actions of ruling and governing nature are of primary importance. ${ }^{11}$

Their implementation in the scope of tasks related to the protection of monuments largely rests on the provincial conservators of monuments. Suffice to point out that the Polish legislator has imposed on them the obligation to implement a fairly extensive list of public tasks. The tasks of the provincial conservator of monuments include in particular: implementation of tasks resulting from the national programme for the protection of monuments and guardianship of monuments; drafting, within the limits of relevant budget allocations, financing plans of protection of monuments and guardianship of monuments; keeping a register and provincial records of listed monuments and collecting documentation in this regard; issuing, in accordance with the competences, decisions, resolutions and certificates in matters specified in the Act and in separate regulations; supervising the correctness of conducted conservation and architectural research, conservation works, restoration works, construction works and other activities in progress concerning monuments as well as archaeological research; organizing and supervising the protection and guardianship of monuments; development of provincial plans of protection of monuments in the event of armed conflict and crisis situations and coordination of activities in the implementation of these plans; dissemination of knowledge about monuments; cooperation in matters concerning the protection of monuments with other public administration bodies and entities that carry out public benefit activities (Article 91 clause 4 of the APM).

10 STAROŚCIAK, J. Prawne formy i metody działania administracji. In: ŁĘTOWSKI, J. - RABSKA, T. (eds.). System prawa administracyjnego. Vol. III. Wrocław, 1978, p. 45.

11 ZIEMSKI, K. Podstawowe kryteria podziału form prawnych działania administracji przyjmowane w polskiej nauce prawa administracyjnego. Próba usystematyzowania. In: HAUSER, R. - NIEWIADOMSKI, Z. WRÓBEL, A. (eds.). System Prawa Administracyjnego. Vol. V. Prawne formy działania administracji. Warszawa, 2013, pp. 53-59. 
In the course of their operation, they generally use legal forms of action available to all administrative bodies. It is possible to diagnose in this respect both the competence of the provincial monument conservator concerning their role in the creation of universally binding legal norms ${ }^{12}$ as well as the resolution of individual cases by way of issuing administrative decisions. ${ }^{13}$ There are also examples of consensual actions such as entering into contracts ${ }^{14}$ and administrative arrangements..$^{15}$ Particular significance should also be attributed to social and cultural actions ${ }^{16}$ of the provincial conservator of monuments as well as their technical and organisational activities..$^{17}$ In the context of public tasks implemented by the monument protection authorities, part of the academic community proposes the distinguishing of further unidentified legal forms of action of the monument conservator. ${ }^{18}$

Against this background, it must be firmly stated that the need to preserve monuments in a proper state requires constant and decisive state interference, which means that the

12 One can here mention their opinions on the provincial, county and commune programmes on the guardianship of monuments (Article 87 clause 3 of the APM), agreeing on drafts and amendments of provincial spatial development plans and local spatial development plans (Article 20 of the APM) or developing provincial monument protection plans in the event of armed conflict and crisis situations (Article 91 clause 4 item 7 of the APM).

13 One should indicate here, among others, issuing permits for: conducting conservation works, restoration works or construction works at a monument listed in the register; performing construction works in the surroundings of the monument; conducting conservation studies of a monument listed in the register of monuments; conducting archaeological research; movement of an immovable monument listed in the register; permanent relocation of a movable monument listed in the register with the disruption of the traditional interior design set in which the monument is located; making a division of an immovable monument listed in the register; changing the purpose served by a monumentor the manner of use of this monument listed in the register; placing of technical devices, boards, advertisements and inscriptions on a monument listed in the register; undertaking other activities that could lead to violation of the historic elements or change in the appearance of a monument listed in the register of monuments; searching for hidden or abandoned movable monuments, including archaeological monuments, with the use of all kinds of electronic and technical equipment and diving equipment (Article 36 of the APM).

14 An example is the conclusion of a grant contract for co-financing conservation works, restoration works or construction works at a monument listed in the register of monuments (Article 73 of the APM).

15 We can mention here numerous competence agreements concluded between provincial conservators of monuments (government administration) and municipal conservators of monuments (local self-government administration), whose subject is the transfer of some of the competences of provincial conservators to the level of municipal self-government. Although the doctrine of administrative law classifies agreements in a group of legal instruments of an administrative nature (among many, cf. BŁAŚ, A. - BOĆ, J. STAHL, M. - ZIEMSKI, K. Działalność konsensualna (dwustronna i wielostronna). In: HAUSER, R. NIEWIADOMSKI, Z. - WRÓBEL, A. (eds.). System Prawa Administracyjnego. Vol. V. Prawne formy działania administracji. Warszawa, 2013, p. 234 et seq.), however, taking into account the origin of all consensual actions, as well as the relatively equivalent position of the parties entering into an agreement, it is impossible to reject the civil law origin of this institution.

16 An example is the obligation to disseminate knowledge about monuments (Article 91 clause 4 item 8 of the APM).

17 For example, issuing certificates confirming the compliance with the obligation to maintain and preserve a monument imposed on its owner, which entitles them to obtain an exemption from property tax (Article 7 clause 1 item 6 of the Act of 12 January 1991 on Local Taxes and Charges, uniform textJournal of Laws of 2018, item 1445, as amended) or the tax on the acquisition of a monument by way of inheritance (Article 4 clause 1 item 9 let. $\mathrm{c}$ and d of the Act of 28 July 1983 on Inheritance and Donation Taxes, uniform textJournal of Laws of 2018, item 644, as amended).

18 SIENKIEWICZ, T. Zażalenie na postanowienie o odmowie wszczęcia dochodzenia jako prawna forma działania wojewódzkiego konserwatora zabytków. Santander Art and Culture Law Review, 2017, no. 1, pp. 93-114. 
legal forms of action of the provincial monument conservator, supported by public authority and taking a governing character, also play a fundamental role in this matter.

\section{A CIVIL LAW CONTRACT AS A CONSENSUAL FORM OF ADMINISTRATION}

The conspicuous asymmetry in the case of the prevailing importance of administrative acts in relation to consensual administration activities confirms the belief that there is a permanent and unchanged standard in the functioning of the administration system in Poland. Actions based on the feasibility of the governing implementation of the objectives of public entities have gained considerable importance in the activities of public administration and are by far the most commonly undertaken measures aimed at the implementation of tasks imposed on them by the national legislator.

The scope of multilateral activities, also aimed at achieving the objectives of the administration, but based on greater or lesser autonomy of the parties is still underdeveloped. ${ }^{19}$ Such legislative solutions - due to, e.g., the greater influence of external entities on the sphere of public administration activities or the stronger emphasis on the idea of civil society in co-administration - undoubtedly have a positive impact on both the effectiveness of undertaken activities and the social perception of the functioning of public authority and its social acceptance. ${ }^{20}$

Contracts have a special place among the consensual forms of actions of public administration. Among the contracts concluded by public administration entities, two types are distinguished: contracts under civil law, regulated by private law, and contracts under administrative law, subject to public law. These agreements are similar in the fact that parties to the legal transaction make consistent declarations of will; they are different, however, in the subject of the contract, the content of the legal relationship between the parties and the legal basis of their conclusion. In any case, the legal institution of the contract has been dynamically gaining importance in the face of changing conditions for the functioning of the administration. Its important value lies in the significant limitation of the unilateral and independent character of activities of the public administration, which is characteristic of administrative acts, thus granting it a certain scope of freedom or flexibility in the undertaken activities. ${ }^{21}$

The most common area where the form of a civil law contract is used in the activities of public authorities is the exercise of competences related to the management of public property. Often, contractual administration activity is also related to the need to

19 The literature emphasizes the fact that the model of the administrative agreement, which has been implemented in many European countries (such as Germany, Greece or Latvia) has not been used in the Polish legal system. In this model, general authorization was given for substitution or auxiliary application of the administrative agreement in all matters that are resolved in the form of an administrative act. Cf. LIPOWICZ, I. Prawne formy działania administracji publicznej - między stabilizacją a potrzebą przełomu. Ruch Prawniczy, Ekonomiczny i Socjologiczny, 2016, no. 4, p. 43.

20 BŁAŚ, A. - BOĆ, J. - STAHL, M. - ZIEMSKI, K. Działalność konsensualna..., p. 235 et seq.

21 BŁAŚ, A. Prawne formy działania administracji. In: BOĆ, J. (ed.): Prawo administracyjne. Wrocław, 2010, pp. 351-352. 
provide the necessary volume of goods for the maintenance of administrative apparatus and material benefits for the society itself. In this respect, the activity aimed at providing citizens with various types of services of basic social importance, referred to as the services administration, is also vital. ${ }^{22}$

It is worth noting that the conclusion of the contract may remain in connection with the actions taken by means of administrative acts. In practice, it takes one of several forms. Firstly, the admissibility of a public entity entering into a civil law contract may depend on the issuing of an administrative act. It then develops or supplements its content. The contract itself may also be subject to approval or registration by another public administration authority. Sometimes, however, the legislator even requires the conclusion of a specific contract, and allows the issuance of an administrative act only in its absence. Ultimately, the contract can even replace an administrative act. ${ }^{23}$

However, it should be remembered that due to the fact that one of the parties to the contract is always a public entity, the possibility of free decision on the conclusion of the contract itself, as well as its content or form are subject to legal regulation. The limitations noticeable in practice apply to the mode of conclusion, choice of form, and the content of the contract itself. As a result, despite its obvious civil law origin, the contract concluded by a public entity is relatively rare in a classic form, and is usually subject to a gradual modification in terms of its constituting elements or it is specified in terms of the intended effects by provisions derived from public law, so that its content is more oriented towards achieving the objectives of administration. ${ }^{24}$

\section{CONCLUSION OF A GRANT CONTRACT AS A CONSENSUAL FORM OF ACTION OF THE PROVINCIAL MONUMENT CONSERVATOR}

In the literature on the monument protection law in Poland, there is basically no reference to the significance of a civil law contract in the implementation of the tasks of provincial monument conservators. This is mainly due to a relatively narrow range of cases, when they are authorized to use this consensual form of realization of tasks related to the protection and guardianship of monuments. However, one should not deny this possibility to the conservator, who is an administrative body.

The legal basis for this type of actions is introduced expressis verbis in Article 73 in conjunction with Article 75 of the APM. These regulations stipulate that a natural person, a self-government unit or another organizational unit, being the owner or holder of a monument listed in the register or having one monument under permanent management or being the owner or holder of a monument listed on the Heritage Treasures

22 LEMAŃSKA, J. Umowa administracyjna a umowa cywilnoprawna. In: SKRZYDŁO-NIŻNIK, I. - SMAGA, M. - DĄBEK, D. - DOBOSZ, P. (eds.). Instytucje współczesnego prawa administracyjnego. Księga jubileuszowa Profesora zw. dra hab. Józefa Filipka. Kraków, 2001, p. 423.

23 ZIMMERMANN, J. Prawo administracyjne. Warszawa, 2016, p. 429 et seq.

24 TRZEWIK, J. O swobodzie kontraktowania w prawie ochrony środowiska. In: KUNIEWICZ, Z. - SOKOŁOWSKA, D. (eds.). Prawo kontraktów. Warszawa, 2017, p. 525. 
List, can apply for a special purpose subsidy from the state budget for co-financing of conservation works, restoration works or construction works at a monument listed in the register or conservation or restoration works at a monument listed on the Heritage Treasures List. At the same time, the minister competent for culture and protection of national heritage or a provincial conservator of monuments may grant subsidies to individuals or entities based on agreements concluded with these individuals or entities. However, the grant for co-financing conservation works, restoration works or construction works at monuments listed in the register is provided by the provincial conservator of monuments from the portion of financial resources of the state budget administered by the voivode (provincial governor) (Article 74 clause 1 item 2 of the APM). Importantly, due to the limited financial capacity of the state budget in terms of targeted subsidies, the financial assistance provided by the provincial monument conservators takes the form of optional actions, which is also confirmed in the wording of the provisions each time stipulating the possibility and not the obligation to grant the subsidy. ${ }^{25}$

The above-mentioned provisions establish the principle of concluding contracts by and between the granting authority and the beneficiaries of targeted subsidies for works on monuments. The possibility of providing this type of financial support based on the contract with the beneficiary of the subsidy is additionally stipulated in the provisions on public finances. ${ }^{26}$ Against this background, one can outline a chronology of obtaining support from a provincial monument conservator, starting with the submission of a grant application by the contractor, followed by the administration body taking a decision in this respect, to be concluded by a contract with the subsidized entity and the granting of the actual subsidy by transferring a specified amount to the bank account. ${ }^{27}$

Analysis of statutory and sub-statutory regulation ${ }^{28}$ dealing with the procedure of concluding subsidy contracts for conservation, restoration or construction works at listed monuments by provincial monument conservators leads to the conclusion that these provisions constitute the basis for limiting the principle of party's autonomy of will. Traditionally, it includes the freedom to perform or not to perform a certain legal act, the freedom of shaping the content of this act and the admissibility of choosing any act, and

25 As observed in the doctrine, the legislator's indication of the form of a civil law contract instead of an administrative act for granting a targeted subsidy by the provincial monument conservator finally removed any doubts as to the legal form of granting financial support to owners of monuments listed in the register. This solution has been consistently supported by the wording of Article 79 clause 1 of the APM indicating that the provisions of the Act of 14 June 1960 - the Code of Administrative Procedure (consolidated text Journal of Laws of 2017, item 1257, as amended) shall not apply to the processing of grant applications.

26 Article 132 in conjunction with Article 150 of the Act of 27 August 2009 on public finance, consolidated text Journal of Laws of 2017, item 2077, as amended.

27 GOLAT, R. Ustawa o ochronie zabytków i opiece nad zabytkami. Komentarz. Kraków, 2004, pp. 139-140.

28 The detailed conditions and procedure for granting targeted subsidies by the provincial monument conservator are set out in a Regulation of 16 August 2017, issued on the basis of Article 80 of the APM by the Minister of Culture and National Heritage and dealing with the targeted subsidy for conservation or restoration works at a monument listed on the Heritage Treasures List as well as conservation, restoration and construction works at a monument listed in the register of monuments, Journal of Laws of 2017, item 1674 [hereinafter: RTS]. 
in the case of multilateral acts, it also consists in the freedom of selection of the other party to the act. ${ }^{29}$ In the case of a grant contract, this autonomy is subject to restrictions both at the stage of concluding the agreement as well as drafting its content.

The commencement of the procedure regarding the conclusion of the contract for targeted grants for conservation, restoration or construction works at monuments listed in the register of monuments is possible only at the request of the person or entity that owns or holds the monument, possibly having a monument under one's permanent management. Submitting an application is therefore obligatory, also when a public entity is the owner of the monument. The need to submit an application to initiate the procedure constitutes a peculiar exception to the general rules of concluding contracts by administrative bodies. In most cases, due to the limited possibility of application of the contractual form in administration as well as on account of the principle of legalism and formal procedures for spending public funds and ways of selecting contractors of public entities and the principles of concluding contracts, ${ }^{30}$ usually the public entity initiates the process leading to the conclusion of the contract. ${ }^{31}$

The application is submitted to the Provincial Monuments Protection Office competent locally according to the location or place of storage of the monument listed in the register (Article 2 item 2 of the RTS). Therefore, there is no possibility of an independent choice of the other party to the legal act by the owner of the monument which is characteristic of the freedom of contracting. The deadline for submitting the application is 30 June of the year in which the targeted subsidy is to be granted - in the case of co-financing of works on a monument listed in the register which were carried out during the period of three years preceding the year of submitting the application, or February 28 of the year in which the targeted subsidy is to be granted - in the case of co-financing of works to be carried out on a monument listed in the register (Article 5 clause 1 item 2 of the RTS).

By limiting the freedom of action of a potential grant beneficiary, the legislator indicated in the implementing provisions the minimum content of the submitted application. It should include at least: name, surname, place of residence and address or name, registered office and address of the owner or holder of the monument listed in the register, or name, registered office and address of the organizational entity holding a monument listed in the register under its permanent management; designation of the authority from which the party applies for the targeted subsidy; the type of work that had been or will be carried out at the monument listed in the register; determination of the amount of the targeted subsidy applied for by the applicant; work schedule; the applicant's statement on their material and human resource capacity ensuring the correct management of works on the monument listed in the register, if the work is to be carried out; total cost estimate of the works. In the case when the applicant is an entity operating a business,

29 SAFJAN, M. Wymiar pragmatyczny (funkcjonalny) zasady autonomii woli. In: (ed.) SAFJAN, M. System Prawa Prywatnego. Vol. I. Prawo cywilne - częśc ogólna. Warszawa, 2012, pp. 335-340.

30 This area is governed by the provisions of the Act of 29 January 2004 - Public Procurement Law, consolidated text Journal of Laws of 2017, item 1579, as amended.

31 STEC, P. Umowy w administracji. Studium cywilnoprawne. Warszawa, 2013, p. 63 et seq. 
documents required by law related to granting state aid ${ }^{32}$ (Article 6 clause 1 and 2 of the RTS) are attached to the application. The correctness of the submitted application is important in that already at the initial stage of the procedure, the application is subject to formal and substantive verification by the administrative body. Therefore, it is of cardinal importance for the future processing of the application under the initiated procedure. If the application contains formal defects, the provincial conservator of monuments calls on the applicant to supplement the application within a period not shorter than 7 days and not longer than 14 days from the date of receipt of the notice. If the formal deficiencies of the application have not been supplemented within the prescribed period, the application will not be further considered (Article 7 clause 1 and 2 of the RTS). An application for granting aid correctly submitted by a potential beneficiary is subject to consideration within 2 months from the date of its submission (Article 8 clause 1 item 1 in fine of the RTS).

Unlike under the previous legal system in force, currently there are no requirements regarding the form of submitting a grant application. ${ }^{33}$ Therefore, the applicant currently has a large degree of freedom in choosing the form in which the application will be made. In addition to the traditional written form, it seems acceptable to submit the application in any other form provided for by the law. In particular, it should thus be possible to prepare the application in a paper document form ${ }^{34}$ as well as an electronic form. ${ }^{35}$

From the point of view of the issue of concluding civil law contracts by public authorities, of particular importance is the limited freedom of contracting in terms of the acceptable degree of shaping the content of the performed transaction. While the common tendency in legal transactions is deciding by the parties themselves about the content of the concluded contract, in the cases when the legislator provides for the possibility of an administrative authority acting by means of the form of a civil law contract, the provisions of the generally applicable law stipulate the required minimum content of the contract (essentialia negotii of the legal act). A similar solution has been included in the implementing provisions in the Regulation on the targeted subsidy issued on the basis of the Act on the Protection of Monuments.

When referring to the contents of grant contracts concluded by the provincial monument conservator, the legislator stipulated two groups of contractual provisions. On the one hand, the legislator indicated mandatory provisions, which - despite using the

32 These are de minimis aid documents referred to in Article 37 clause 1 and clause 2 items 1 and 2 of the Act of 30 April 2004 on proceedings in matters concerning state aid, consolidated text Journal of Laws of 2018 , item 362 , as amended.

33 Under the previous Regulation of the Minister of Culture of June 6, 2005 on granting a targeted subsidy for conservation, restoration and construction works on a monument listed in the register of monuments, Journal of Laws No. 112, item 940 with amendments, it was required to submit an application for subsidy in accordance with the template constituting Annex 2 to this Regulation. In particular, it quoted the list of required documents attached to the application in the form of further annexes.

34 Pursuant to Article $77^{2}$ of the Act of 23 April 1964 - the Civil Code, consolidated text Journal of Laws of 2018, item 1025, as amended [hereinafter: CC], in order to observe the requirement of a document form of a legal act, it is sufficient to submit a declaration of intent in the form of a document in a way which allows the person making the declaration to be determined.

35 As it follows from Article 781 of the CC, in order to observe the requirement of an electronic form of a legal act, it is sufficient to submit an electronic declaration of intent signed with a qualified electronic signature. 
phrase "in particular" in the wording of the provisions - must, however, be included in such contracts. ${ }^{36}$ At the same time, they were grouped depending on whether the subsidy is to be a form of aid for planned activities concerning the maintenance of monuments, ${ }^{37}$ or it will be a reimbursement of costs of already completed works. ${ }^{38}$ On the other hand, parties to the transaction may also include other provisions in the text of the contract, entered therein in accordance with the general principle of freedom of contract. ${ }^{39}$ In this respect, we should distinguish both subjectively essential terms (accidentalia negotii, pertaining to, e.g., provisions concerning contractual penalties - Articles 483-485 of the $\mathrm{CC}$ ), as well as subjectively and objectively non-essential terms (naturalia negotii, such as the place of performance - Article 454 of the CC).

When defining the subject matter of the contract, however, each time Article 76 clause 1 item 1 and 2 of the APM should be taken into account, as it specifies that the subsidy may be granted only for co-financing of expenditures necessary for conservation, ${ }^{40}$ restoration ${ }^{41}$ or construction works ${ }^{42}$ at a monument listed in the register, established on the basis of a cost estimate approved by the provincial monument conservator, to be carried out in the year of submitting the grant application by the applicant or in the

36 STUPIENKO, E. Zakres, formy stosowania i charakter prawny tzw. umowy dotacyjnej. Krytyka Prawa. Niezależne studia nad prawem, 2014, no. 1, vol. 6, p. 439.

37 In this case, the targeted grant contract for work on the monument listed in the register, which will be carried out in the year of submitting the application or in the year following the year of submitting the application includes in particular: the designation of the parties and the time and place of its conclusion; the scope of planned works and the deadline for their completion; the amount of the targeted subsidy and the date and mode of its payment; deadline for using the targeted grant not longer than by 31 December of a given budget year; the mode of controlling the performance of the targeted grant contract; the date and manner of settlement of the granted subsidy; deadline for returning the unused portion of the targeted grant not longer than 15 days from the deadline for completion of the work specified in the contract; terms of termination of the contract (Article 10 clause 1 of the RTS).

38 As it follows from Article 10 clause 2 of the RTS, the targeted grant contract for works on a monument listed in the register carried out in the period of 3 years preceding the year of submitting the application includes in particular: the designation of the parties and the time and place of its conclusion; the scope of works carried out at the monument listed in the register and the date of their completion; the amount of the targeted subsidy and the payment deadline; the mode of controlling the performance of the targeted grant contract; the date and manner of settlement of the targeted subsidy; stipulation that the amount of the targeted grant is reduced by the amounts of fines paid to the applicant by the contractors of the work and interest on the sum of money transferred to the applicant under the targeted grant; terms of termination of the contract; additional conditions and reservations that ensure purposefulness and rationality of spending the targeted subsidy.

39 Pursuant to Article 353of the CC, contracting parties may establish a legal relationship at their own discretion, as long as its content or purpose does not contradict the character (nature) of the relationship, the statute or the rules of social coexistence.

40 They include the implementation of activities aimed at protecting and preserving the monument's historic elements, inhibiting the processes of its destruction and documenting these activities (Article 3, item 6 of the APM).

41 They relate to the implementation of activities aimed at exposing the artistic and aesthetic values of the monument, including, if necessary, supplementing or reconstructing its parts, and documenting these activities (Article 3, item 7 of the APM).

42 They consist in construction works under the provisions of the Act of 7 July 1994 - Construction Law, consolidated text Journal of Laws of 2018, item 1202, as amended, including the construction, reconstruction, installation, renovation or demolition works carried out at a monument or in the surroundings of a monument and involving a building with installations and technical equipment, or a building constituting a single technical and functional structure together with installations and devices, or, finally, street furniture. 
year following the submission of the application, or expenditures necessary for conservation, restoration or construction works at a listed monument, which were carried out in the period of three years preceding the year in which the applicant applies for a grant. At the same time, the targeted subsidy, pursuant to an extremely casuistic legal stipulation, may only cover the necessary outlays ${ }^{43}$ including: preparation of technical and conservation expertises; conducting conservation or architectural research; preparation of conservation documentation; drafting of a conservation and restoration program; preparing a building permit design in accordance with the provisions of the Construction Law; preparing a design for the reconstruction of interior design; protection, preservation and consolidation of the monument's historic elements; structural stabilization of the components of the monument or their reconstruction to the extent necessary for the preservation of this monument; renewal or completion of plasters and architectural cladding or their complete restoration with the preservation of the colour characteristic of this monument; reconstruction of the damaged appurtenance of the monument, if the reconstruction does not exceed $50 \%$ of the original elements of this appurtenance; renovation or complete reconstruction of windows, including frames and shutters, external door and door frames, roof trusses, roof coverings, gutters and downpipes; modernization of the electrical installation in wooden monuments or monuments, which have original components and appurtenances made of wood; construction of damp proofing; replenishment of outlines of earthwork defensive architecture and immovable archaeological monuments with individual landscape forms; activities aimed at exhibiting the existing, original elements of historic park or garden layouts; purchase of conservation and construction materials necessary to carry out works at monuments listed in the register; purchase and set-up of anti-burglar and fire protection and lightning protection installations (Article 77 of the APM). The above-mentioned catalogue is closed, which means that it is not possible to grant a subsidy for works outside its scope, as well as those currently being carried out at a listed monument (and therefore works that have not yet been completed). ${ }^{44}$

The subsidy may be granted in principle only in the amount corresponding to $50 \%$ of the indicated outlays necessary for the works carried out at a monument listed in the register (Article 78 clause 1 of the APM). However, exceptionally, if the monument in question has a unique historical, artistic or scientific value, or if this monument requires technologically complex conservation, restoration or construction works, or if the condition of the monument requires action, the subsidy may cover up to $100 \%$ of the expenditure necessary to perform works at the monument (Article 78 clause 2-3 of the APM). Also in this respect, the contractual freedom of the parties is therefore subject to significant limitations.

43 In the academic literature, in contrast to upgrading or excessive outlays, the necessary outlays are all kinds of expenses, the aim of which is to preserve things in a condition suitable for normal use, such as repairs and renovation, sowing, keeping animals, or taxes. Cf. CHERKA, M (eds.). Ustawa o ochronie zabytków i opiece nad zabytkami. Komentarz. Warszawa, 2010, p. 277. The necessary outlays are thus aimed at ensuring the conditions for normal use of things. Cf. judgement of the Supreme Court of 10 August 1988, Ref. no. III CRN 229/88, OSNC 1990, no. 12, item 153.

44 Judgement of the Provincial Administrative Court of 8 February 2007, Ref. no. I SA/Wa 1810/06, LEX no. 342577) 
Ultimately, the mere transfer by the administrative body of the financial resources granted to the beneficiary under the targeted grant should take place on dates that provide financing for the obligations resulting from the work on a monument listed in the register of monuments or as reimbursement of expenses incurred. It should be transferred to the bank account indicated by the applicant (Article 11 of the RTS).

Against the background of the comments on the procedure for concluding the grant contract, several deviations from the general rules applicable to contractors and used in common practice become conspicuous. They are concentrated on shaping the limits of the autonomy of will of contracting parties by means of provisions of the generally applicable law. This is due to the characteristic situation, which involves an administrative authority as one of the parties to the legal transaction, as well as the fact that the legal design of the contract results from the provisions of public law. At the same time - as it seems - the listed differences are within the limits of deviations justified by the participation of public entities in the transaction.

An analysis of the legal framework for the conclusion of a targeted grant contract for co-financing of conservation, restoration or construction works on a monument listed in the register by and between the provincial monument conservator and the beneficiary shows that it is an example of a legal act of a contractual nature, ${ }^{45}$ which is characteristic of civil law. Due to the fact, however, that its legal existence results directly from public law regulations, it somehow escapes the traditional civil law regulations. When attempting to characterize it, it should be defined as a non-Code nominate contract, which is a special form of a grant contract regulated by the Public Finance Act. In both cases, the legislator has statutorily indicated essentially similar essentialia negotii of the legal act. Thus, if the parties intend to conclude a valid grant contract, it must contain the normative content corresponding to the statutory framework of this type of legal relationship. Additional characteristic features of this agreement are also the established scope of potential contractors, as well as the purpose of the grant (subsidy) justifying the reason for its conclusion.

The legal framework of this contract demonstrates its similarity to consensual legal acts involving reciprocal obligations and accruing gratuitous financial benefits. In exchange for the financial benefit, provincial monument conservators do not gain any asset value that could be the equivalent of their own performance. Apparently, it is also a causal agreement, because the performance by a public authority occurs in order to achieve a certain legally determined objective (causa) by the contractor, which is to protect the public interest in achieving the proper level of guardianship of a monument. At the same time, on account of the content of the contract being imposed by the legislator, it is akin to the category of contracts of adhesion.

45 BĄCZYK, M. - BORODO, A. - CILAK, M. - JUSTYŃSKI, T. - WAŁACHOWSKA, M. Zobowiązania cywilnoprawne w regulacjach prawa finansowego. Prawo Budżetowe Państwa i Samorzqdu, 2015, no. 2, p. 92. 


\section{RECAPITULATION}

Despite many positive changes, the functioning of the system of protection of cultural heritage, including monuments, in Poland after the period of political transformation is still a multifaceted problem that needs to be solved. This applies to a large extent also to the issue of huge needs related to financing the protection and guardianship of monuments. ${ }^{46}$

An important element of the national system of financing the restoration of monuments is the capacity of the provincial conservator of monuments to conclude subsidy contracts for conducting conservation, restoration and construction works at monuments listed in the register of monuments. The conducted analysis of the legal basis of its conclusion reveals the civil law nature of the contract even though public law provisions underlie its conclusion and a public authority is indicated as one of its obligatory contractors. The civil law nature of the contract is maintained even despite the sometimes quite significant interference of the legislator in the freedom of contracting the parties to the contract are entitled to.

However, the characteristics of the existing legal framework are of little importance if they are separated from a practical evaluation of their implementation. Analysis of the data obtained through access to public information regarding the practical application by provincial conservators of monuments of the regulations on targeted grants for conservation, restoration and construction works on monuments listed in the register brings generally positive conclusions. ${ }^{47} \mathrm{On}$ their basis, one can observe a significant ${ }^{48}$ and, what is important, even recently growing interest of monument owners in individual regions of the country ${ }^{49}$ regarding this form of public support. Importantly, the upward trend can also be noted in relation to the amount of planned financing of activities. ${ }^{50} \mathrm{It}$ is also significant that practically in the case of all Provincial Monuments Protection Offices, the group of applying monument holders interested in obtaining financial support also included entities belonging to the public finance sector.

The adopted form of granting support to monument holders should therefore generally be considered as correct. The grant contract as a form of consensual action of the

46 BÖHM, A. - DOBOSZ, P. - JASKANIS, P. - PURCHLA, J. - SZMYGIN, B. Raport na temat funkcjonowania systemu ochrony dziedzictwa kulturowego w Polsce po roku 1989. Kraków, 2008, pp. 26-29.

47 Requests for access to public information concerning the financing under the framework of targeted grants for the protection and guardianship of monuments over the past 3 years were sent electronically to provincial monument conservators on 5 September 2018.

48 An example of this is the Monuments Protection Office of the Lubuskie Province in Zielona Góra, where each year the number of applications for grants oscillates between 60-70, or the Provincial Monuments Protection Office in Lublin, where the number of applications fluctuates around 100 each year.

49 This tendency is visible, for example, in the case of applications submitted to the Provincial Monuments Protection Office in Opole, the Monuments Protection Office of the Wielkopolska Province in Poznan or the Provincial Monuments Protection Office in Kraków.

50 In the case of the Provincial Monuments Protection Office in Wrocław, in 2015 the amount of financing for 28 accepted and completed applications amounted to approx. PLN 815,000. In 2016, with 27 applications, it was PLN 780,000, in 2017, with 22 applications, it was PLN 770,000 PLN, while in 2018 the financing of 64 applications totalled almost PLN 5.5 million. Another example is the Provincial Monuments Protection Office in Lublin, which in 2015 and 2016 financed respectively 78 and 67 applications in the amount of PLN 1.25 million while in 2017 it financed 73 applications in the amount of PLN 1.2 million. 
provincial conservator of monuments ensures an appropriate level of protection not only of the public interest but also of the private interest. This is particularly conspicuous against the background of the scale of practical use of funds allocated for this purpose in the state budget. This support should be considered as a significant stream of funding, effectively supporting the holders of monuments in their conservation activities and guardianship of monuments.

In this context, one should positively evaluate the current framework of formal requirements for the conclusion of a grant contract, which, after the legislative changes, are adequate to the degree of financial support granted, which seems favourable for potential beneficiaries of grants. And although it does seem rare, one should also appreciate the approach of the national legislator who has created a transparent system of financial support for the protection of monuments. A particularly positive solution in this respect in the procedure related to the conclusion of the contract is the postponement of the beneficiaries' documentary obligations to the stage after the subsidy has been granted or the stage of subsidy settlement in the case of refund (Article 12 of the RTS). ${ }^{51}$

doc. JUDr. Jacek Trzewik

The First Chamber of Civil Law

Faculty of Law, John Paul II Catholic University of Lublin

trzewik@kul.pl

51 However, some observations may be made regarding the current system of financing monument protection. As it follows from the post-audit statement of the Supreme Audit Office, the weaknesses of the system may be traced, for example, to the failure to provide local government authorities with information on subsidies granted by the central government administration, which may result in duplication of financing of identical conservation activities (post-audit statement by the Supreme Audit Office in Zielona Góra of 22 May 2015, reference no. LZG.410.002.02.2015, audit no. P/15/00 regarding the cooperation of provincial monument conservators and local self-government bodies), or to the failure to exercise due diligence in the course of the contract conclusion procedure, especially when completing the necessary documentation (post-audit statement by the Supreme Audit Office Branch in Lublin of 10 September 2013, ref. no. LLU.4114.07.01.2013, audit no. I/13/013 regarding the financing of the protection and guardianship of monuments in the Lublin Province by the Lublin Province Monument Conservator in Lublin). 